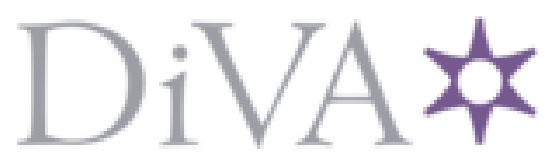

http://www.diva-portal.org

This is the published version of a paper presented at LARES 2015 .

Citation for the original published paper:

Sundfors, D., Bonde, M. (2015)

Sustainability Metrics for Commercial Buildings in Sweden.

In:

N.B. When citing this work, cite the original published paper.

Permanent link to this version:

http://urn.kb.se/resolve?urn=urn:nbn:se:kth:diva-200312 


\title{
Sustainability metrics for commercial buildings in Sweden
}

\author{
David Sundfors \\ Department of Real Estate and Construction Management, \\ KTH Royal Institute of Technology \\ Skanska Sweden AB \\ Magnus Bonde \\ Department of Real Estate and Construction Management \\ KTH Royal Institute of Technology
}

\begin{abstract}
Environmental rating systems typically focus on building characteristics at a specific point in time. From an investment and valuation perspective, actual performance over time should be the most important. This paper investigates how frontrunners on the Swedish green building market actually monitors their new buildings. Newly constructed commercial buildings today usually come with a high degree of technically advanced installations and a wide range of monitoring possibilities. This provides us with the possibility to monitor a buildings in-use performance. By performing a selected case study, conducting a survey and follow-up interviews among Swedish real estate companies and finally study available industry information, this paper studies what key performance indicators real estate developers choose to monitor as well as how they go about to collect and use the data. By doing this, we can get an idea of what is already monitored and to which extent. The case study also provides insight into what is technologically possible. A comparison of this gathered data is then made with information that investors and property valuers can be expected to be interested in and it is found that this to a large extent is information that the frontrunners already gather, but it is not made publicly available. One area where important information is lacking is however data about indoor climate.
\end{abstract}

\section{Keywords}

Green Building, Monitoring, Building Performance 


\section{Introduction}

Many developers of new commercial buildings aspire to be Green/Sustainable. Even though no uniform definition exists of what makes a building green, most of these developments focus on energy efficiency, to avoid hazardous materials and create good indoor comfort. In order to evaluate these parameters, different environmental assessment tools have been developed and are now used worldwide. In Sweden, the most common schemes for assessing commercial buildings are BREEAM, LEED (Cole \& Valdebenito, 2013) and Miljöbyggnad ${ }^{1}$ (Denell \& Bonde, 2015; Malmqvist, et al., 2011). These schemes mainly focus on the construction phase, and less on the operating/maintenance phase (O'Sullivan, et al., 2004), at least in their basic version.

In recent years, both LEED and BREEAM have developed certificates, or subcategories in their certificates, that are tailored towards different situations, such as existing buildings (Cole \& Valdebenito, 2013), but these systems are rather new on the market and not too many have started working with them yet. As argued in Sundfors et al (2016), it is important both from an investor perspective and from an environmental perspective not only to know that the building was green at a certain historical point in time, often according to theoretical calculations, but also to know the actual environmental characteristics today. Therefore, it is important to study the monitored performance of the current green buildings in-use today, in order to know if the qualities still holds up or not. The importance of such measurable metrics for monitoring the buildings (environmental) performance is also emphasized by Crawley and Aho (1999). From a life cycle analysis perspective, this is also interesting as the operation phase of the buildings lifespan has an impact on the whole building life cycle energy usage; even though the size of it depends on building usage, type of construction etc. (Liljenström, et al., 2015; Ramesh, et al., 2010).

Systems for monitoring the current environmental characteristics of a building are especially important as the building in use often do not perform as well as projected in the design phase (Hitchcock, 2002). Both Piette (2001) and O'Sullivan (2004) argue that a better monitoring with suitable performance metrics could reduce this difference, as it could provide the operating staff with the necessary feedback. Using this information as decision basis for both short terms decision about adjustments of technical systems and for more long-term decisions to modify the building installations/retrofit the building, as illustrated in Fig. 1 would be beneficial (BLC in the figure refers to Building Lifecycle). Such a systematic working procedure should bring about a better indoor environment, as well as energy savings (Costa, et al., 2013) (Piette, et al., 2001). Wang et al. (2012) also accentuate advantages with monitoring building energy usage, as it gives a more accurate overview of the building's energy usage. Being able to show the buildings performance over a specific period of time also has a large potential to add value to the building (Ellison \& Sayce, 2007).

With this background in mind, it would be interesting to investigate how actors in the real estate sector in Sweden work with monitoring their commercial buildings, especially buildings where they aim to get an environmental certificate in one of the leading international or national environmental classification systems. What exactly is considered important to monitor and how do they plan to develop it further in the near future? To sum up, the aim of this paper is to study the front runners in

\footnotetext{
${ }^{1}$ Miljöbyggnad is a Swedish environmental assessment scheme, which assesses the following parameters: Energy, Indoor Environment and construction materials.
} 
sustainable real estate in Sweden today, and look at how they work with systems for continuous monitoring of their buildings..

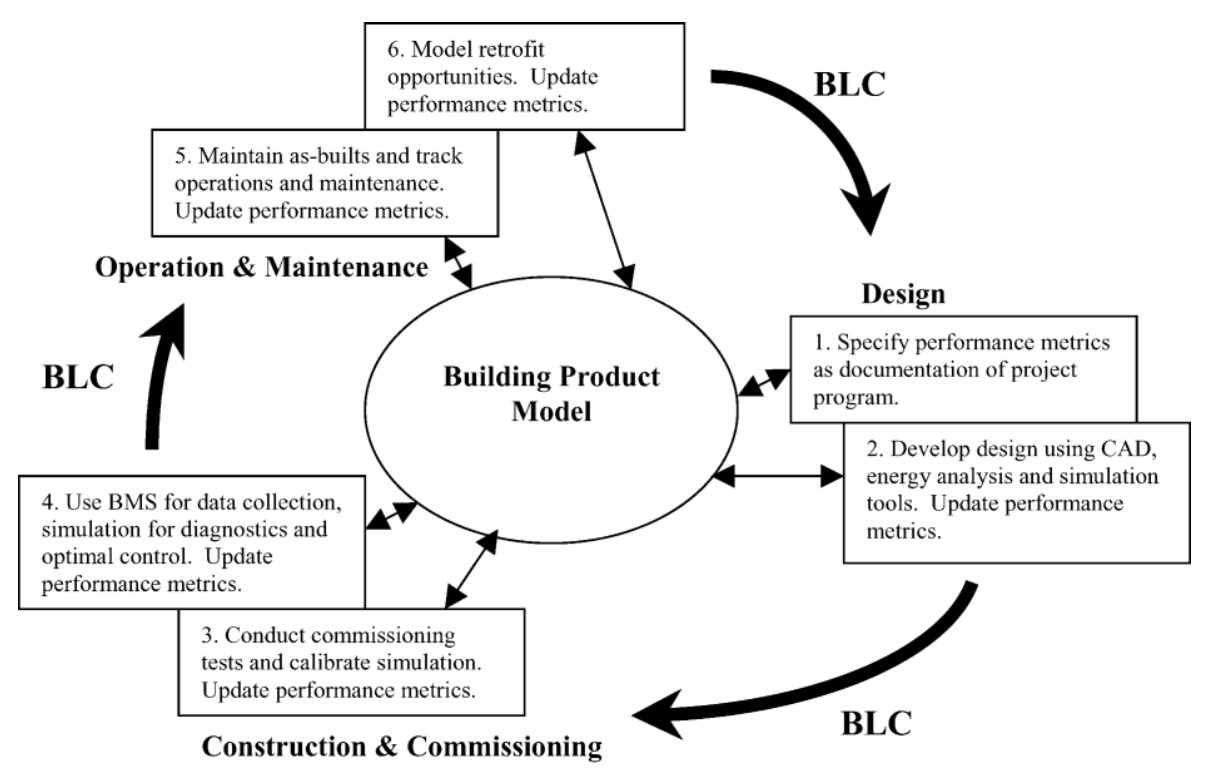

Fig. 1. Lifecycle performance metric tracking scenario (O'Sullivan, et al., 2004).

\section{Method}

Using several approaches were necessary in order to collect information about the possibilities of monitoring sustainability in existing buildings and how Swedish real estate companies do this.

First, two newly constructed buildings and one projected development were chosen for case studies, two of them in collaboration with Skanska. The three cases are Uppsala Entré, Väla Gård and Utbildningshuset at KTH. The cases where to some extent chosen for convenience, but also, and more importantly, as representatives of modern commercial buildings in Sweden, with a strong focus on sustainability and technological development. As such, the cases can be described as being critical cases of an information-oriented selection as described by Flyvbjerg (2006). That is also an argument for choosing a building that is now under construction as it provides an additional insight into the ambitions for planned buildings with a strong sustainability focus. Following Stake (1994) the case studies have an intrinsic approach, as the main purpose is to describe and understand the cases studied. Using the classification scheme in Yin (2009), the study is categorized as a single-case (embedded) study, as different embedded units ("cases") are studied in order to reveal information about the main research question (case).

The necessary data about the three cases were collected through interviews and reviews of reports and other documents, but also elements of participant observation in Skanska. The data gathering method is therefore a combination of analyzing documents, interviews and direct participation and observation, in which the researcher plays a more active role. This also gives the researcher the opportunity to observe the case "from the inside" (Flick, 2009; Yin, 2009). The interviews were indepth and conducted in a semi-unstructured format, scheduled for a specific date and time and 
conducted around a short set of open-ended questions. This provides the opportunity to ask new questions that emerge during the interview and are well suited for gaining a deeper understanding of the subject at hand (DiCicco-Bloom \& Crabtree, 2006). The people selected for the interviews where professionals directly involved in the project, e.g. working with creating reports showing the performance of the building, or planning the installation systems that will provide the necessary performance indicators.

In order to provide a broader perspective on the monitoring of commercial developments an online survey containing 28 questions was sent out to 58 different professionals from a total of 30 different real estate companies within the commercial real estate industry. The persons had leading positions within sustainable development in their respective companies and there were people responsible for property management within a certain region. Out of the invited 58, 13 respondents completed the survey, giving a responding quota of $22 \%$. The list of companies included several of the largest privately owned real estate companies in Sweden. The survey, apart from multiple-choice answers, also contained the possibility of additional comments from the respondents.

From the respondents that gave additional comments and expressed a more ambitious attitude towards monitoring their buildings, three where approached for follow-up interviews concerning their respective companies' philosophy in sustainable development. Those interviews followed the same format as the ones carried out in the first three case studies.

\section{Results from Case studies}

\subsection{Uppsala Entré}

Uppsala Entré, situated in central Uppsala, is a six-floor building that was commissioned in the beginning of 2012. The rentable commercial area is approximately 12500 square meters, consisting of office space, retail and cafés/restaurants. The building has a LEED (Core \& Shell) Gold certificate, which is the second highest certificate in the LEED scheme.

In order to uphold the building performance over time, an extensive building monitoring system, consisting of $\mathbf{4 2 6}$ measuring points, was implemented. All data records are stored in a database, which is managed by the developer Skanska. The system is not designed to alert if any measurement breach a threshold limit value, but instead to alert if the technical installations are malfunctioning. The data from the scheme is the groundwork for the quarterly reports of the building performance, following the standard Energy Agreement 12 (Energiavtal 12), as outlined by Sveby².

The energy metering is logged in different categories; electricity and heating/cooling. In order to separate the property energy ${ }^{3}$ and operational energy ${ }^{4}$ (in accordance with Swedish building code), several metering devices (EN-certified) have been placed throughout the building. As heating and cooling are provided via the district heating/cooling grid, the energy provider supplies the metering

\footnotetext{
${ }^{2}$ A cross sectional organization with the purpose to standardize energy metering standards in the built environment

${ }^{3}$ Property energy - Energy for heating, cooling, hot water and electricity for building services necessary for the use of the building

${ }^{4}$ Operational energy - electricity used to operate computers, copiers, refrigerators/freezers, lighting etc.
} 
devises. In order to provide accurate data, both water temperature as well as the water flow has to be measured. These logs are then integrated into a software application, which computes the transfer of heating/cooling for any given time period.

The ventilation scheme recovers heat from the exhaust air to heat the supply air, using a heat exchanger. The metering devices are placed in the ducts to be able to monitor the air pressure. In addition; air humidity, airflow, $\mathrm{CO}_{2}$-levels as well as air damper activity is recorded. The magnitude of the ventilation in the separate rooms is depending on the $\mathrm{CO}_{2}$-levels, as this provides an appropriate estimator of the number of people present.

Water is registered through conventional water metering. However, as to separate the tenant usage from the remaining, multiple metering devices have been dispersed throughout the building. The meters, provided by the local water supplier, are EEG type approved. These are based on the EN1434 standard and revised by a third party accredited by SWEDAC (Swedish Board for Accreditation and Conformity Assessment) (Engström, 2014).

\subsection{Väla Gård}

This real estate consists of two separated two-story buildings, which have been connected via an annex. In all, the building consists of about 1650 square meters (70 workstations). As for the technical installations, the building uses geothermal heating/cooling, solar cells to generate electricity and has a demand controlled ventilation scheme.

The building was commissioned in 2012, and had the ambition to be a net zero energy building, following the definition by Sveriges Centrum för Nollenergihus (Erlandsson, et al., 2012). The criteria's is based on the work by Sartori et al. (2012), which are summarized in Table 1. In addition, the building is certified LEED (New Construction) Platinum.

\begin{tabular}{|c|c|}
\hline Criteria & Swedish definition \\
\hline Physical boundary & $\begin{array}{l}\text { In accordance to the Swedish building regulations. Hence, in general, the } \\
\text { physical boundary is the building itself }\end{array}$ \\
\hline Balance boundary & $\begin{array}{l}\text { Energy used for heating, cooling and dehumidification, ventilation and } \\
\text { humidification, hot water and permanently installed lighting of common spaces } \\
\text { and utility rooms are included in the balance. Other services are not included } \\
\text { in the balance (e.g. computers, copiers, TVs etc.) }\end{array}$ \\
\hline Boundary conditions & Set point for heating $\left(+21^{\circ} \mathrm{C}\right)$ and internal heat gains is defined \\
\hline Weighting system & Weighted energy is used, with static and symmetric weighting factors \\
\hline Balancing period & 1 year \\
\hline Type of balance & Balance is calculated based on import/export \\
\hline Energy efficiency & Fulfilment of Swedish Passive house criterion \\
\hline $\begin{array}{l}\text { Measurement and } \\
\text { verification }\end{array}$ & $\begin{array}{l}\text { To enable verification of the energy performance, energy metering must be } \\
\text { separated into heat and electricity }\end{array}$ \\
\hline
\end{tabular}

Table 1: Summary of Swedish Net ZEB definition (Sartori, et al., 2012)

The monitoring system consists of 300 measuring points, which was in operation by May 2013. The ventilation scheme is a Demand Controlled Ventilation system (DCV), which adjusts to motion (via presence sensors), air temperature and $\mathrm{CO}_{2}$-levels. The DCV is interconnected with the ventilation decks, in which monitor instruments that measures air flows, duct pressure and air temperature are installed. In addition, the relative humidity $(\mathrm{RH})$ is logged for the separate rooms. 
To monitor the energy usage, 18 energy meters have been installed in the building. In accordance with Swedish building code, the property and operational energy is logged separately. The building uses geothermal energy to supply the building with heating and cooling, as well as to heat the tap water. The tap water consumption is only logged for billing purposes, with a meter provided by the local water supplier.

All data is stored in the building's mainframe computer on an OPC ${ }^{5}$ server, connected to a database where it can be accessed and analyzed. Data from the DCV system (including ventilation engines) can also be accessed via a web-based application. In order to minimize working hours, the real estate developer sought to implement a system, which process and analyze the data into a weekly standardized report. These automated reports could then be complemented with a more thorough revision, produced manually with lesser intervals (Kempe, 2014).

\subsection{Utbildningshuset KTH}

This building was, when the study was carried out, yet to be constructed, but is currently (september 2016) under construction. The ambition levels are high and the concept for the building is interesting enough to be part of the case study. As part of the campus for KTH (Royal Institute of Technology) in Stockholm, there is an idea to make the building as a sort of live in lab where the students will be able to access the information about the building as part of their education. The building will consist of 3500 $\mathrm{m}^{2}$ over 7 floors that are designed for teaching and learning. It is planned to be in commission at the end of 2016. Apart from extensive possibilities to measure and monitor the building, a strong focus is set on low energy consumption, aiming for a level at least half of the guide value from the Swedish building regulations (BBR). Among the available certificates on the market, the decision landed on the Swedish certificate Miljöbyggnad, with the highest grade, gold, as target. Miljöbyggnad has a more narrow focus than for example LEED or BREEAM in that it is only the building itself that is of interest. Location of the building and activities within it are of no consequence. Since it deals with fewer parameters, the only way to achieve higher grade is to perform better for these parameters. The system was created with this specific purpose in mind to be tailored for Swedish conditions and easy to use.

The system that is going to monitor the building is specified in the technical descriptions in the specifications. There is no demand for the actual number of sensors required, but six different types of sensors are described that are needed to acquire the desired data from the building. These sensors will gather data concerning energy consumption, heating, cooling, air pressure, air flow, temperature and some sensors are also built into the walls and the foundation in order to provide information of how the relative moisture levels change over season and over time. These sensors specifically comes with a higher level of uncertainty, since one cannot be sure if changes are because of the material or the sensor itself.

Energy will be measured and presented in accordance with Swedish energy regulations and it will show the amount of energy bought from renewable energy sources versus conventional energy bought. The ventilation system will be a FTX system with heat recovery and ventilation will be controlled by $\mathrm{CO}_{2}$ levels. Water will be logged for the entire building rather than by each floor since the tenant is the same for the entire building.

\footnotetext{
${ }^{5} \mathrm{OPC}=\mathrm{OLE}$ for Process Control
} 
The ambition for the building is also that the focus on low energy consumption and extensive logging and monitoring will be beneficial for the costs of maintenance and operation. However, as there is not much data available to prove this, KTH has had a hard time to get this into the contract with the owner of the building, a government company that owns and runs just about all the university buildings in Sweden. They see the higher construction costs and want to raise the rent accordingly, making the negotiations tougher than necessary when the user wants improved performance. One way to lower the costs for KTH has been to apply for government funds from the Swedish Energy Agency which has been granted. This means that apart from logging and storing the data concerning the performance of the building, KTH is also obliged to send data to the Swedish Energy Agency to display that the building performs as promised (Eriksson, 2014; Incoord; Edberg, Olle;, 2015).

\section{Results from survey}

\subsection{Survey}

The survey (see Appendix A) was sent out to 58 different employees at several of the largest private companies in commercial real estate in Sweden. Out of those, there were 13 that completed the survey, giving an answer frequency of just above $22 \%$. The survey consisted of 26 different questions concerning which certification system they use, if any, how the companies measured the performance of their commercial buildings, what do they measure, how often and how is the data treated.

The first questions concerned if they worked with any certification system and if so, how much of their real estate portfolio was certified. Out of the respondents, three (21\%) answered $<5 \%$, two (14\%) answered $10-20 \%$, seven $(50 \%)>20 \%$ and one was not sure. They all measure property electricity consumption on a regular basis, eleven of them (85\%) does it every month, the final two have access to the figures on an hourly basis. The information is then stored in a central database for the entire corporation. The odd exception being one company that is buying a subscripted online service from the municipality that they are active in, this service gathers, stores and presents most of the metrics that the company is interested in. How this data is later used does differ a bit, but not very much, aside from one company, they all use it for statistics, follow-ups and operation optimization. Most also report the figures to tenants and in some cases a third party such as Swedish Energy Agency as part of an agreement. One company also uses the information for yearly climate impact calculations.

When it comes to tenant electricity consumption, there are four (31\%) that do not measure it and nine $(69 \%)$ that does. Seven of those that do measure it do it once a month (54\%). The company that has bought that service uses the online service, called e-report, for this. The other companies store the data in their central database. The data is used mainly for information to tenants, statistics and followups. Three of the companies use it for operation optimization and one also provides an app, where the tenant can see their consumption and follow changes, trends and savings in real time.

They all but one measure water monthly and the data is collected in the central database and used for mainly statistics and follow-ups. Five of the companies work with the data in their operating optimization. The e-report is used for this data as well. Another common feature is presencecontrolled ventilation. Eleven (85\%) of the responding companies answer that they have it in at least some buildings, six of these (46\%) have it in more than $10 \%$ of their buildings. 
The next part of the survey dealt with air quality, and unfortunately, the question was apparently formulated in an ambiguous way since the replies implicated misunderstandings from some of the respondents. What can be said from the responses is that measuring air quality in the sense of measuring particle levels aside from $\mathrm{CO} 2$ seems very unusual, and just about never done in a systematic way.

The following part of the survey dealt with waste, and it turned out that nine (69\%) do measure waste, five of those (38\%) separate tenant waste from waste from maintenance and operations. The last part dealt with thoughts on the future and metrics that are desirable but difficult to get reliable data on, and the main issue turned out to be tenant electricity. It should be noted that the survey had no questions regarding energy; this is mainly because in Sweden you are obligated to measure energy.

To sum it up, most companies that responded to the survey do work quite extensively with monitoring their buildings in various ways, as well as working with several different certificates. Worthy to note is that half of the respondents, albeit being representatives of a group of early adopters, said that more than $20 \%$ of their portfolio had one certificate or more.

\section{Results from the interviews}

\subsection{First interview}

Company 1 has chosen to work primarily with LEED. They feel that it is more encompassing than the Swedish system that is more directed towards just the building, and that their requirements for certification are a bit too low for their standards. LEED had a different advantage in that it had a system for volume certification, meaning that certificating the existing property portfolio could be done much easier. Because of this, $71 \%$ of Company 1 properties are certified, a figure that is comparatively very high. Company 1 has a philosophy with a very high focus on climate footprint and has ambitions to certify all their properties to as high a level as can be done. They have seen the role that real estate plays in the climate debate and are determined to act accordingly, and see it as their responsibility to do what they can to create sustainable real estate for the future. LEED EB\&OM is in that regard the type of system that they work the most with and they feel that it works. EB\&OM has several parameters that you have to present, not just show that you measure them, but the actual figures. Because of this, most of Company 1 properties have rather extensive installations for measuring performance, specifically in energy, water and waste. What they do feel that they lack is access to the tenant electricity, since focus is more and more going towards a supply-chain philosophy when it comes to sustainable work and improvement, much as other industries have already gone into. Company 1 feels that the existance of different certification systems on the market is not really a problem. In Sweden there are three, perhaps four, major ones and that does not feel like too many. Of course, there are new versions of all these systems coming out on a regular basis, but that is as it should be, since development and technology are constantly pushing the boundaries. In fact, if anything, the existence of several systems on the market is probably pushing the development more aggressively, which is a good thing. In the longer perspective, Company 1 (the interviewee) is hoping and believing that sustainable properties and construction will not only be the norm, but legislation will actually be put in place to prevent real estate that are bad for the environment and climate. One 
thing they feel that is needed to look into is the follow up on green bonds and options that are created in order to finance green buildings, but as of today there is no specific tool or system to evaluate if the end result actually came out as green as intended (Denell, 2016).

\subsection{Second interview}

Company 2 is a commercial real estate company based in Gothenburg with their entire portfolio in Gothenburg. Because of this, they make use of some regional benefits and systems in order to be updated on their buildings. The local energy company has an e-report available for an additional extra fee that is not too high, and thanks to this, Company 2 can have access to the performance of all their buildings just a few clicks away. The report can register such things as energy, water and waste. The information available about the energy also includes such things as usage, amount of energy bought, type of energy (however, as of today, not able to differ between green and ordinary energy) and when Company 2 does build it, they can also measure the amount of energy produced on site from solar power. The report system is logged in on the meters in the buildings, so Company 2 can have information by the hour. As it stands, they only produce monthly reports in order to check status and look for trends and malfunctions that have to be addressed. Company 2 works predominantly with three different certification systems, Green Building (EU certificate that only focuses on energy), BREEAM (Company 2 was involved in the first BREEAM certified property in Sweden, it was a demand from the client) and the Swedish system Miljöbyggnad. The main focus is on Miljöbyggnad, and that is the system they have chosen in order to try to certify a large part of their existing portfolio in. The main idea is to get at least the basic certificate for as many buildings as possible, but some buildings are simply not suited for certification, depending on age and so on. It is also of course a question of cost and revenue. They feel that Miljöbyggnad is easy to work with, and that a benefit for the system is that you are simply told which parameters to work with, where as in BREEAM and LEED, you need to choose your parameters, that is something that creates more work and extra costs (De Hollanda, 2016).

\subsection{Third Interview}

Company 3 owns and operates around 55 commercial buildings in Stockholm. Whereas they do not have a very strong focus on certificates, they are working towards certifying their portfolio in BREEAM In-use. What they do have is a very strong focus on energy and monitoring functionality in their buildings. The installation systems in just about all their buildings have a very extensive system of sensors, giving maintenance and operation a very powerful tool to optimize the performance of the building. They do measure water and waste as well, but that is not where the primary focus is. Ventilation is controlled by temperature, as opposed to $\mathrm{CO}_{2}$ levels. They have done the occasional measurement of $\mathrm{CO}_{2}$ emissions, but since the values were so low, that is also not a focus area. Their ambition is to be able to monitor the functionality and energy of the buildings with the aid of constant logs. The focus on consistent logging of the functionality of different areas in a building is something that they are, if not alone, then at least among the few to focus on. This means an enormous amount of data and of course, not everything can be kept forever, but Company 3 still has access to a large part of the history for their buildings. A problem with extensive monitoring is that when you are looking at functionality (for example a ventilation damper or elevator), in order to have any idea about whether that function is working properly, you need reference values, and these need to be calculated separately for each sensor. If you have hundreds or thousands of sensors, that makes for a lot of reference values that need to be calculated in order to have something to calibrate against. Company 
3 has this for the most part, but there is still a long way to go before all buildings are up to the desired standard (Rosén, 2016).

\section{Example of Key performance indicators (KPI) used by the industry}

As in most industries, private initiatives to gain more complete knowledge about the industry are abundant in the real estate sector in Sweden. One such initiative is from the firm Incit. Among their products are a book series that collect statistics for comparison for different types of buildings. Their latest book for offices is the 36th edition, and provides statistics for 20 different KPIs for operational costs. These are: administration, property tax, property fee, insurance, Energy use - heating, energy use - cooling, electricity use - property, electricity use - tenant, water consumption, supervision and maintenance - ground, supervision and maintenance - building, supervision and maintenance installations, waste disposal, cleaning, troubleshooting maintenance, planned maintenance - ground, planned maintenance - building outdoor, planned maintenance - building indoor, planned maintenance - installations and rent level. The data is collected from a large number of companies, but also from their own services as a consulting firm within the real estate industry. Overall, the material covers a total building area of $900000 \mathrm{~m}^{2}$ with an average area per building of $7400 \mathrm{~m}^{2}$, and roughly 120 commercial buildings. The office buildings included have a varied disposition concerning age that looks like follows:

\begin{tabular}{|l|c|}
\hline $\begin{array}{l}\text { Year of } \\
\text { construction }\end{array}$ & $\begin{array}{l}\text { Percential } \\
\text { disposition }\end{array}$ \\
\hline-1957 & 38 \\
\hline $1958-1967$ & 12 \\
\hline $1968-1974$ & 3 \\
\hline $1975-1989$ & 31 \\
\hline $1990-1999$ & 11 \\
\hline $2000-$ & 5 \\
\hline
\end{tabular}

Table 2_Age of buildings in the Incit data-base

Directly relatable to this article are the parameters dealing with energy, electricity, water and waste. This show, together with the performed survey, that at least to some extent, monitoring of several of these parameters are already in place (Incit AB, 2016).

\section{Analysis}

The three buildings present interesting cases for how monitoring of building performance can be carried out. Today, the technology is available to monitor (and assess) a large number of building performance indicators, as to evaluate the building's sustainable features. The monitoring also makes it possible to more effectively fine-tune the building's installations in order to improve the building's energy performance and indoor environment. However, the interviews revealed that the information from the monitoring is used a bit differently. While the maintenance staff at Väla Gård used it to finetune the building's installations, the operating staff at Uppsala Entré used it to control that the building performed at an acceptable level (that is, in line with the agreement with the tenant). In the third case, 
as mentioned earlier, the information is also supposed to be a part of the education at the university and accessible for students for school projects.

The survey did not provide answers from a large number of actors on the commercial real estate market, but out of the ones that did complete the survey, several are among the top 20 largest actors in the commercial real estate industry, including the largest private real estate company in Sweden. This means that the answers from the survey still provide a useful insight into the behavior and trends in the market. It is also necessary to take into consideration that the companies that did complete the survey also belonged to the group commonly referred to as early adopters in sustainability, so the answers cannot be said to represent the industry as a whole. This was not the intention anyway, as the purpose was to see just how these early adopters worked with monitoring in order to identify the state of the art in the industry.

From the answers, there are some interesting points to mention. First, almost all of the companies that responded have certified at least one building, most of them more than $20 \%$ of their stock. So certification is certainly something very relevant, and this is in line with the responses of the focus group that claimed almost all larger commercial buildings being constructed in Sweden today are certified by one or several of four certificates; LEED, BREEAM, Miljöbyggnad and Green Building. In fact, none mentioned any other certificate. This interest in certification gives an indication that sustainability characteristics are important for marketability.

As far as the performance indicators go, the survey did not bring about any large surprises; electricity, water, waste and $\mathrm{CO}_{2}$ is commonly measured. They measure it, collect it and use it in much the same way. There are of course differences, but considering the number of respondents, it could be dangerous to draw any more general conclusions based on them. In the section with an open question with room for further comments, three of the respondents wished for access to more information concerning tenant activity, such as tenant electricity use and tenant waste.

The indicators gathered by Incit are interesting, even though the data still does not represent more than 120 buildings, and it seems like the companies in the real estate industry are not that interested in sharing their knowledge about their individual buildings.

The indicators that have been identified in the Incit initiative which has an environmental focus, the three cases in this paper and the ones represented in the survey is summarized in the table below. 


\begin{tabular}{|c|c|c|c|c|}
\hline KPI from Incit & $\begin{array}{l}\text { Monitored KPI } \\
\text { Case } 1\end{array}$ & $\begin{array}{l}\text { Monitored KPI } \\
\text { Case } 2\end{array}$ & $\begin{array}{l}\text { Monitored KPI } \\
\text { Case } 3\end{array}$ & $\begin{array}{l}\text { Inquired KPIs from } \\
\text { Survey }\end{array}$ \\
\hline energy use - heating & $\begin{array}{l}\text { energy use - } \\
\text { heating }\end{array}$ & energy use - heating & $\begin{array}{l}\text { energy use - } \\
\text { heating }\end{array}$ & (redundant) \\
\hline energy use - cooling & energy use - cooling & energy use - cooling & $\begin{array}{l}\text { energy use - } \\
\text { cooling }\end{array}$ & (redundant) \\
\hline $\begin{array}{l}\text { electricity use - } \\
\text { property }\end{array}$ & $\begin{array}{l}\text { electricity use - } \\
\text { property }\end{array}$ & $\begin{array}{l}\text { electricity use - } \\
\text { property }\end{array}$ & $\begin{array}{l}\text { electricity use - } \\
\text { property }\end{array}$ & $\begin{array}{l}\text { electricity use - } \\
\text { property }\end{array}$ \\
\hline $\begin{array}{l}\text { electricity use - } \\
\text { tenant }\end{array}$ & $\begin{array}{l}\text { electricity use - } \\
\text { tenant }\end{array}$ & $\begin{array}{l}\text { electricity use - } \\
\text { tenant }\end{array}$ & $\begin{array}{l}\text { electricity use - } \\
\text { tenant }\end{array}$ & electricity use - tenant \\
\hline water consumption & water consumption & water consumption & $\begin{array}{l}\text { water } \\
\text { consumption }\end{array}$ & water consumption \\
\hline waste disposal & (no info) & (no info) & (no info) & waste disposal \\
\hline cleaning & $x$ & $x$ & $x$ & $x$ \\
\hline$x$ & Temperature & Temperature & Temperature & $\mathrm{x}$ \\
\hline $\mathrm{x}$ & $\mathrm{CO}_{2}$ emissions & $\mathrm{CO}_{2}$ emissions & $\mathrm{CO} 2$ emissions & $\begin{array}{l}\text { Indoor air quality } \\
\left(\mathrm{CO}_{2}\right)\end{array}$ \\
\hline$x$ & Air pressure & Air pressure & Air pressure & $x$ \\
\hline
\end{tabular}

Table 3 Overview of KPI's used

Concerning the cases, the matter of waste disposal was never covered, hence the lack of information on that specific parameter.

It looks like there is some degree of consensus about which performance indicators to assess, but the interviewed real estate developers seemed to await an even more standardized method to monitor building performance. The lack of consensus could be because the majority of environmental assessment schemes do not request any monitoring in their assessment criteria's. This is unfortunate, as it has been shown that a building's performance often underperform the intended performance levels. In addition, agreements where the developer has to provide reports on the completed building's ongoing performance is very seldom used, a least in Sweden. What was also revealed in the interviews with the real estate developers is the confidence that the environmental certification process more or less ensure good building performance.

Earlier studies, for instance Eichholtz et al. (2010) and Fuerst and McAllister (2011) indicate that sustainable building brings about an economic additional value, such as rent and sales price premiums. However, for these premiums to survive the test of time, the buildings have to show that the benefits of sustainability (lower energy usage, better indoor environment etc.) are constant and lasting over time. If these benefits where to be uncertain, the tenants and real estate buyers will not be willing to pay any premiums.

Noteworthy in this study is that none of the developers had decided to monitor the actual quality of the indoor air quality (with exception of $\mathrm{CO}_{2}$-levels). This is probably due to that most ventilation systems do not have the capacity to monitor and log for instance particle levels, and therefore additional equipment would have to be used. However, from the authors' point of view this would be beneficial in order to be able to verify a good indoor air quality. What also has been emphasized by Jarnehammar et al. (2015), is the monitoring of the building materials. As they deteriorate over time, 
they may cause unhealthy emissions in the future. However, in order to evaluate this, monitoring devises would have to be built into the building components, a very complex procedure that would require a broad cooperation between real estate developers, construction entrepreneurs and suppliers.

This paper has focused on commercial buildings alone, for offices, restaurants, cafés and a school building for university. Yet three different approaches was discovered from three different interviews; the larger owner with a big portfolio over a large geographical area that focuses strongly on certifying as many buildings as possible and a high ambition in CSR, the somewhat smaller owner with a strong regional focus and limited possibilities in their focus on sustainability that chooses a more simple assessment scheme and knows their limits as to which buildings they can afford to certify, and finally the rather wealthy owner that does not think too much about market value but have a business in owning and operating prime real estate with a long term perspective. They choose to basically ignore the certificates unless their tenants demands it, but at the same time, they arguably knows the most about their buildings since they put such a large emphasis on monitoring and optimizing the operation of their buildings. It would be very interesting in a further study to conduct a larger number of interviews among the real estate actors and see if there are other approaches and if some sort of categorization depending on size, structure and strategy could be discerned.

\section{Conclusions and recommendations}

The aim of this study was to review how leading real estate developers and property owners monitor in-use building performance today. Investors and valuation professionals should be expected to demand more complete knowledge about a buildings actual performance over time, and what this paper show is that at least some of the information required to answer those demands is already being gathered. However, it is not necessarily made public, the owners mostly keep the information for themselves in order to monitor and, at least to some degree, tune the operations of their buildings.

It is also important to note that some of the selected companies had no short run interest in the market value of their buildings, and that the company that put the most effort into monitoring their buildings is a long-term owner that focus on operating their buildings in an efficient way. This provides an insight into which kind of approach different real estate owners can take towards a sustainability assessment scheme.

It would seem that in many cases, we know more about our buildings than we think we do, but the information is privy to the owners and not necessarily made official and public. Perhaps the first step towards gaining more knowledge about how a building's sustainable performance might affect the market value is simply legislating that more information about the building should be made available. The technology is there, the possibilities are there and in many cases, it looks like the information is actually already there, we just need access to it, or rather, the owners need more incentives to gather and share that information.

A category that quite thoroughly is measured and monitored in the buildings from the case study, but is largely unaccounted for in the industry KPIs from Incit and is largely not addressed by the companies in the survey, is indoor air quality and indoor environment. Here there seems to be a gap, while even the new buildings do not measure levels of hazardous particles in the indoor air, all three have systems 
for measuring $\mathrm{CO}_{2}$ levels to operate and calibrate their ventilation. In Sweden, there does not seem to exist any real interest in measuring levels of particles on a regular basis, but the answer to that is that the few measurements that have been done show such low levels of particles even in high traffic crossings at city centers, that it has yet to become an issue.

\section{References}

Bonde M., L. H. L. S., 2009. Hur värderas energieffektiva och miljöanpassade kommersiella fastigheter?, Stockholm: Kungliga Tekniska Högskolan.

Cole, R. J. \& Valdebenito, M. J., 2013. The importation of building environmental certification systems: international usages of BREEAM and LEED. Building Research \& Information, 41(6), pp. 662676.

Costa, A., Keane, M. M., Torrens, I. J. \& Corry, E., 2013. Building operation and energy performance: Monitoring, analysis and optimisation toolkit. Applied Energy, Volume 101.

Crawley, D. \& Aho, I., 1999. Building environmental assessment methods: applications and development trends. Building Research and Information, Volume 07, pp. 300-308.

Denell, A. \& Bonde, M., 2015. Hållbarhet och Miljö. In: Fastighetsekonomi och fastighetsrätt Fastighetsnomenklatur. s.l.:Fastighetsnytt Förlag AB, Stockholm.

DiCicco-Bloom, B. \& Crabtree, B. F., 2006. The qualitative research interview. Medical Education, Volume 40, pp. 314-321.

Eichholtz, P., Kok, N. \& Quigley, J. M., 2010. Doing well by doing good? Green office buildings. American Economic Review, December, Volume 100, pp. 2494-2511.

Ellison, L. \& Sayce, S., 2007. Assessing sustainability in the existing commercial property stock. Property Management, 24(3), pp. 287-304.

Flick, U., 2009. An introduction to qualitative research 4th edition. Gosport, Hampshire, Great Britain: Ashford Colour ress Ltd.

Flyvbjerg, B., 2006. Five Misunderstandings About Case Study Research. Qualitative Inquiry, 12(2), pp. 219-245.

Fuerst, F. \& McAllister, P., 2011. Eco-labeling in commercial office markets: Do LEED and Energy Star offices obtain multiple premiums?. Ecological Economics, April, Volume 70, pp. 1220-1230.

Hitchcock, R. J., 2002. CiteSeerX. [Online]

Available at:

http://citeseerx.ist.psu.edu/viewdoc/download?doi=10.1.1.114.4117\&rep=rep1\&type=pdf

Kajornboon, A. B., 2005. Chulalongkorn University Language Institute. [Online]

Available at: http://www.culi.chula.ac.th/Research/e-Journal/bod/Annabel.pdf

Lützkendorf, T. \& Lorenz, D. P., 2006. Using an integrated performance approach in building assessment tools. Buuilding Research \& Information, Volume 34:4. 
Malmqvist, T. et al., 2011. A Swedsih environmental rating tool for buildings. Energy, Volume 36, pp. 1893-1899.

Office of Energy Efficiency \& Renewable Energy, 2015. Building Performance Database. [Online] Available at: http://energy.gov/eere/buildings/building-performance-database [Accessed 02 2015].

O'Sullivan, D. T. J., Keane, M. M., Kelliher, D. \& Hitchcock, R. J., 2004. Improving building operation by tracking performance metrics throughout the building lifecycle (BLC). Energy and Buildings, November, Volume 36, pp. 1075-1090.

Piette, M. A., Kinney, S. S. \& Haves, P., 2001. Analysis of an information monitoring and diagnostic system to improve building operations. Energy and Buildings, October, Volume 33, pp. 783-791.

Ramesh, T., Prakash, R. \& Shukla, K. K., 2010. Life cycle energy analysis of buildings: An overview. Energy and Buildings, October, Volume 42, pp. 1592-1600.

Rosén, P., 2016. Chief Operations and Technology Officer [Interview] 2016.

Sartori, I., Napolitano, A. \& Voss, K., 2012. Net zero energy buildings: A consistent definition framework. Energy and Buildings, May, Volume 48, pp. 220-232.

Stake, R. E., 1994. Case Studies. In: Y. S. Lincoln, ed. Handbook of Qualitative Research. Thousand Oaks: Sage Publications, pp. 236-247.

Todd, J. A. and Fowler K. F., 2010. Measuring Performance of Sustainable Buildings. [Online] Available at: http://www.wbdg.org/resources/measperfsustbldgs.php

[Accessed 02 2015].

Wallström, T., 2013. Miljöcertifiering av byggnader - En studie av certifikatets immateriella värde, Stockholm: KTH Arkitektur och Samhällsbyggnad.

Wang, S., Yan, C. \& Xiao, F., 2012. Quantitative energy performance assessment methods for existing buildings. Energy and Buildings, December, Volume 55, pp. 873-888.

Yin, R. K., 2009. Case Study Research - Design and Methods 4th Edition. s.I.:SAGE Publications, Inc..

\section{Empiric references}

De Hollanda, P., 2016. Sustainability Coordinator [Interview] 2016.

Denell, A., 2016. Chief Sustainability Officer [Interview] 2016.

Engström, M., 2014. Energy Engineer, Skanska Sweden [Interview] (17 09 2014).

Eriksson, S., 2014. Project Leader, KTH [Interview] (05 11 2014).

Erlandsson, M. et al., 2012. Kravspecifikation för nollenergihus, passivhus och minienergihus, s.l.: Sveriges centrum för nollenergihus. 
Incit AB, 2016. REPAB Fakta 2016: Kontor - Nyckeltal för kostnader och förbrukningar. 36 ed. Mölndal: Incit AB.

Incoord; Edberg, Olle;, 2015. Technical Description - Specifications. Stockholm: s.n.

Jarnehammar, A., Gyllenram, R. \& Eliasson, M., 2015. Vilken relevans har miljömärkningen?.

Stockholm: s.n.

Kempe, P., 2014. Lågan - Väla Gård i Helsingborg. [Online]

Available at: http://www.laganbygg.se/vala-gard-i-helsingborg 69

[Accessed 02 2015].

Liljenström, C. et al., 2015. Byggandets klimatpåverkan, s.I.: s.n.

Skanska AB, 2013. How we define Green. [Online]

Available at: http://group.skanska.com/Sustainability/Our-Journey-to-Deep-Green/How-we-define-

Green/

[Accessed 02 2015]. 


\section{Appendix}

\begin{tabular}{|c|c|c|c|c|c|c|c|c|c|}
\hline 芭 & 鏟 & $\underset{\mathscr{y}}{\mathscr{x}}$ & 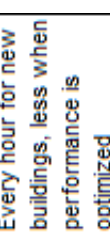 & & 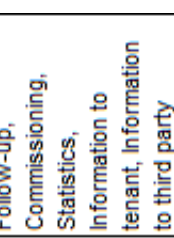 & $\stackrel{\mathscr{m}}{\forall}$ & 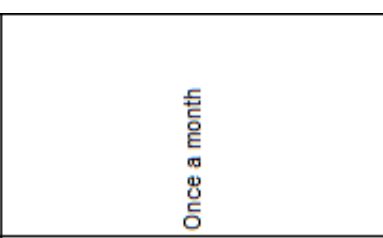 & 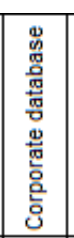 & 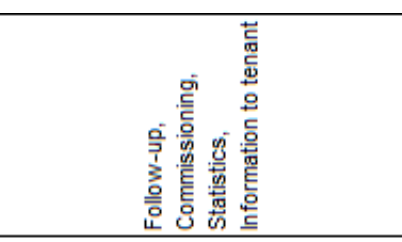 \\
\hline 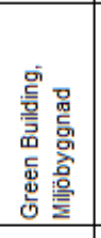 & 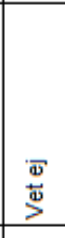 & 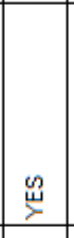 & 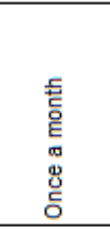 & 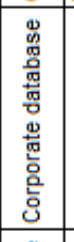 & 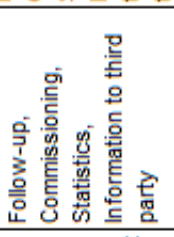 & $\stackrel{\mathscr{\Perp}}{\boldsymbol{\nu}}$ & 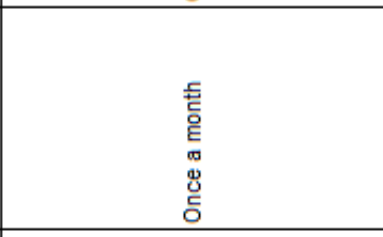 & 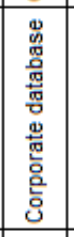 & 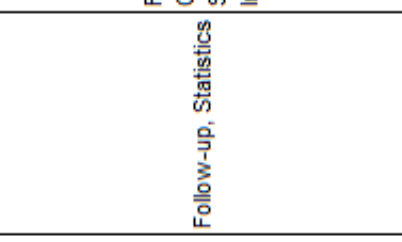 \\
\hline 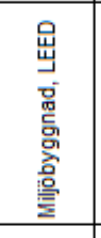 & 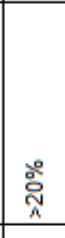 & $\stackrel{\mathscr{H}}{\rightleftharpoons}$ & 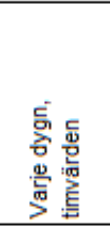 & 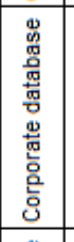 & 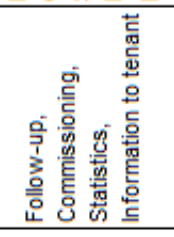 & $\stackrel{2}{z}$ & 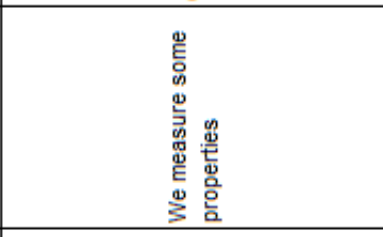 & 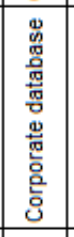 & 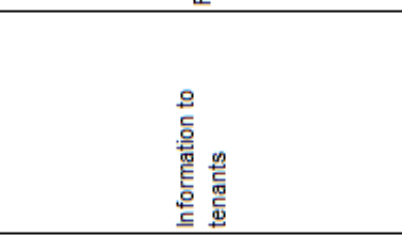 \\
\hline & 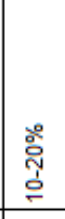 & $\stackrel{\leftrightarrow}{\check{\nu}}$ & 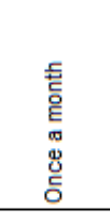 & 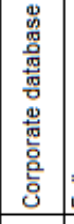 & 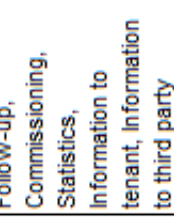 & $\stackrel{\mathscr{\nu}}{\forall}$ & 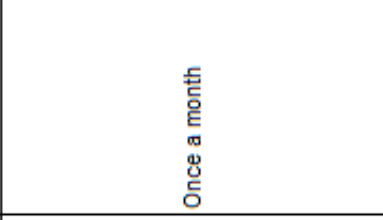 & & 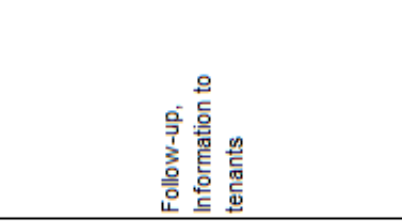 \\
\hline 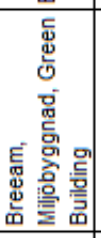 & & 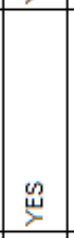 & 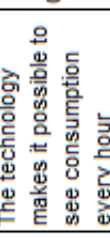 & 믕 & 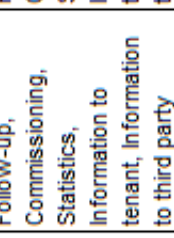 & $\stackrel{\circ}{z}$ & 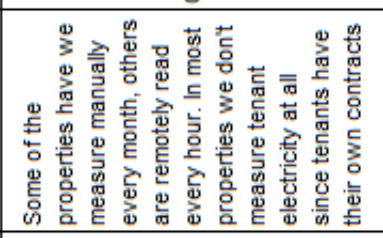 & 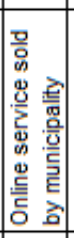 & 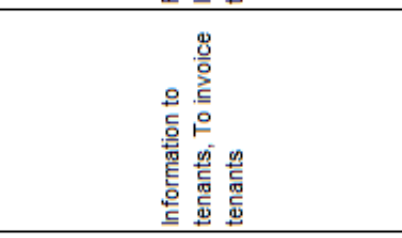 \\
\hline 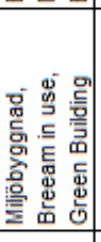 & ڤั. & $\stackrel{\mathscr{P}}{\succ}$ & 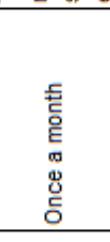 & 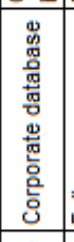 & 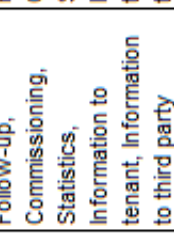 & $\stackrel{\mathscr{W}}{\Sigma}$ & 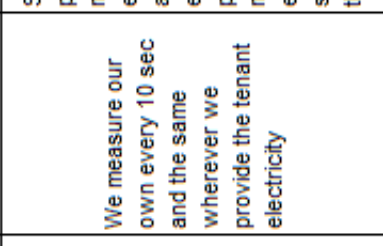 & 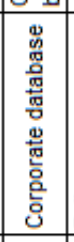 & 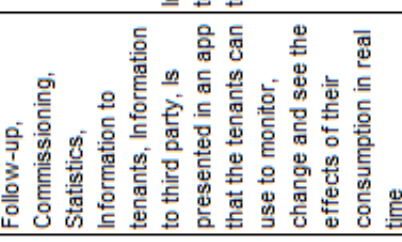 \\
\hline 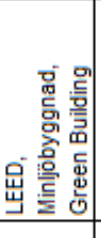 & ๖ั้ & $\stackrel{\leftrightarrow}{\check{\nu}}$ & 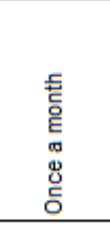 & 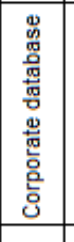 & 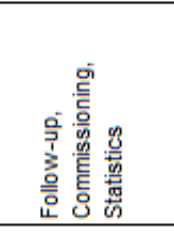 & $\stackrel{\mathscr{U}}{\check{\Sigma}}$ & 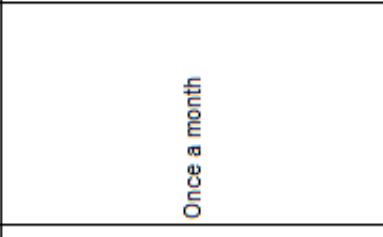 & 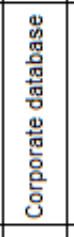 & 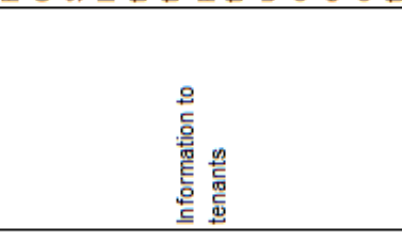 \\
\hline$\overline{0}$ & $\approx$ & 8 & & $\begin{array}{l}0 \\
\end{array}$ & & $\hat{\sigma}$ & 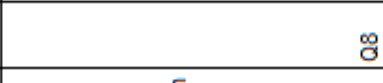 & 8 & \\
\hline 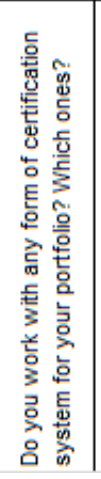 & 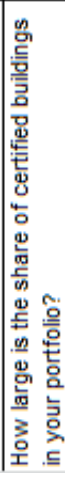 & 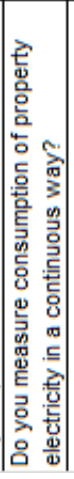 & 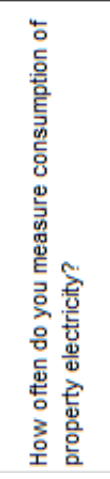 & 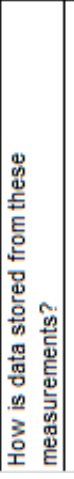 & 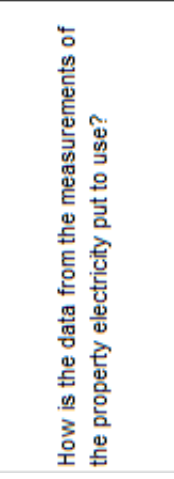 & 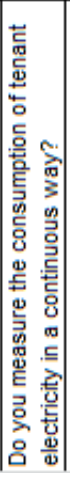 & 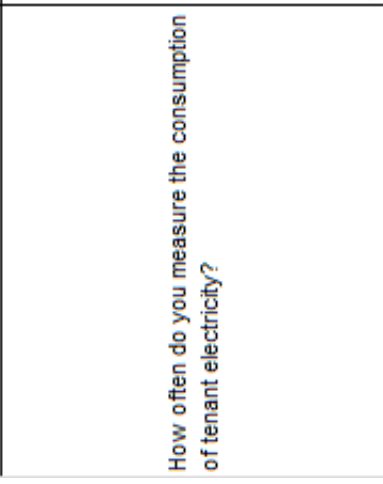 & 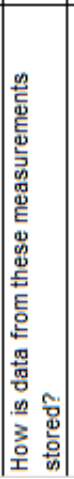 & 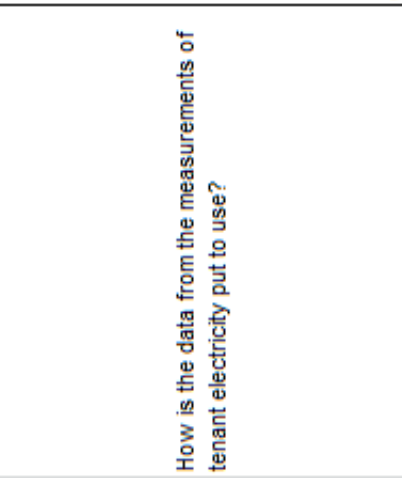 \\
\hline
\end{tabular}




\begin{tabular}{|c|c|c|c|c|c|c|c|c|c|c|c|c|c|c|c|}
\hline$\stackrel{\mathscr{w}}{\nu}$ & 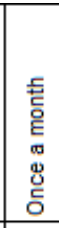 & 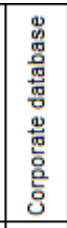 & 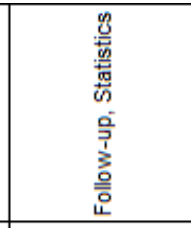 & 울 & $\begin{array}{l}\text { 产 } \\
\text { 姜 } \\
\text { 莒 }\end{array}$ & $\stackrel{\mathscr{H}}{\forall}$ & ఫั้ & 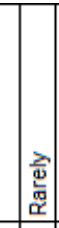 & 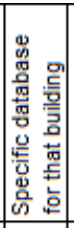 & 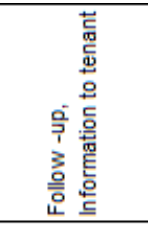 & 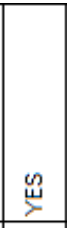 & $\stackrel{\circ}{\circ}$ & $\stackrel{\mathscr{্}}{\check{\nu}}$ & & \\
\hline 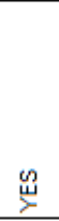 & 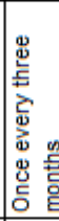 & 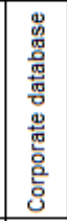 & 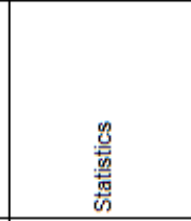 & $\stackrel{\mathscr{्}}{\forall}$ & 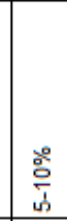 & 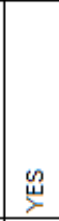 & 윳 & 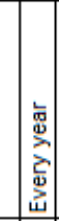 & 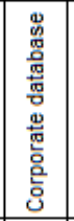 & 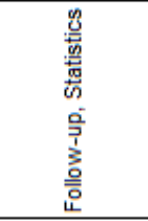 & $\stackrel{\mathscr{\nu}}{\breve{\gamma}}$ & : & $\stackrel{\mathscr{्}}{\breve{\nu}}$ & & \\
\hline$\stackrel{\mathscr{ٌ}}{\forall}$ & 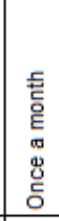 & 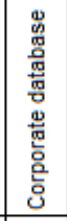 & 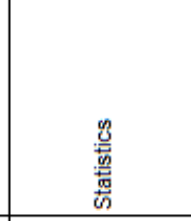 & $\stackrel{\mathscr{\nu}}{\forall}$ & $\frac{\circ}{n}$ & 울 & 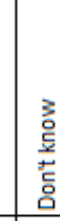 & & & & $\stackrel{\mathscr{m}}{\forall}$ & $\frac{\stackrel{\circ}{\circ}}{\circ}$ & 울 & & \\
\hline$\stackrel{\mathscr{H}}{\forall}$ & 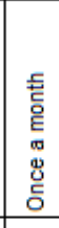 & 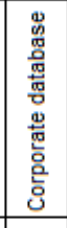 & 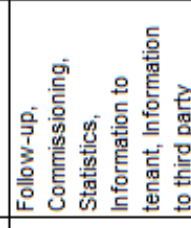 & 崫 & $\stackrel{\circ}{\circ}$ & $\stackrel{\circ}{z}$ & & & & & $\stackrel{\mathscr{w}}{\rightleftharpoons}$ & \begin{tabular}{|l}
$\circ$ \\
\end{tabular} & $\stackrel{\mathscr{m}}{\succ}$ & 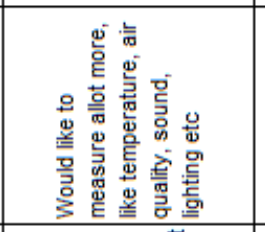 & 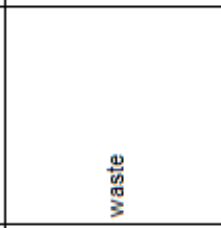 \\
\hline$\stackrel{\mathscr{\varphi}}{\vec{\nu}}$ & 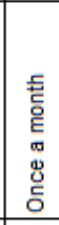 & 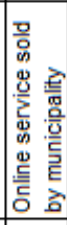 & 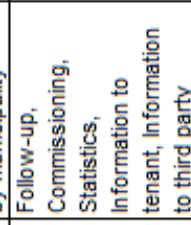 & $\stackrel{\leftrightarrow}{\rightleftharpoons}$ & $\begin{array}{l}\text { 言 } \\
\text { 美 } \\
\text { 总 }\end{array}$ & & $\begin{array}{l}\text { 言 } \\
\text { 童 } \\
\text { 总 }\end{array}$ & 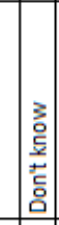 & $\begin{array}{l}\text { 言 } \\
\text { 章 } \\
\text { 言 }\end{array}$ & & 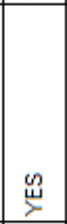 & $\frac{\circ}{\circ}$ & q & 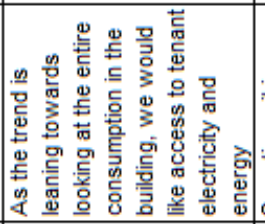 & 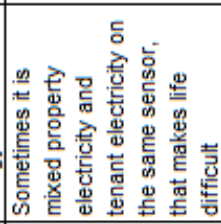 \\
\hline$\stackrel{\mathscr{P}}{\nu}$ & 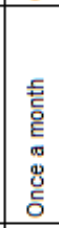 & 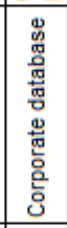 & 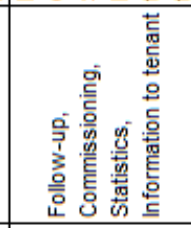 & $\stackrel{\mathscr{H}}{\rightleftharpoons}$ & $\frac{\circ}{\circ}$ & 울 & $\begin{array}{l}\text { 訁े } \\
\text { 产 } \\
\text { 㝘 }\end{array}$ & 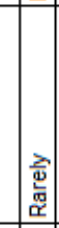 & & & $\stackrel{\mathscr{ٌ}}{\check{\nu}}$ & $\frac{\circ}{\grave{a}}$ & 울 & 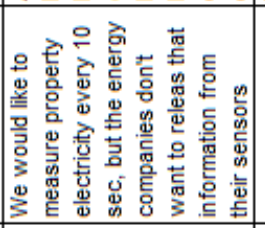 & 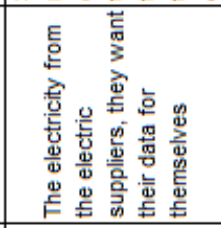 \\
\hline 울 & & & & $\stackrel{\mathscr{H}}{\forall}$ & \%ั & $\stackrel{\mathscr{H}}{\forall}$ & 帘 & 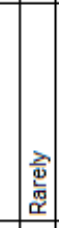 & 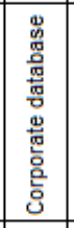 & 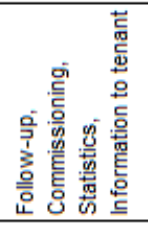 & $\stackrel{\circ}{z}$ & & & & \\
\hline$\overline{0}$ & ธี & $\frac{\mathrm{m}}{\mathrm{a}}$ & $\frac{7}{0}$ & $\frac{n}{0}$ & $\stackrel{\circ}{0}$ & cे & & $\frac{\circ}{6}$ & ชิ & $\overline{\check{g}}$ & สี & $\approx$ & ปี่ & वี & č \\
\hline 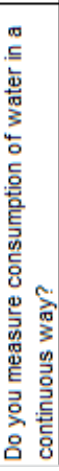 & 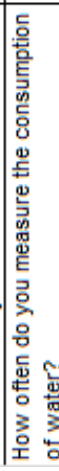 & 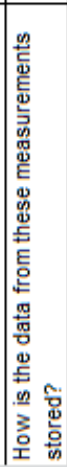 & 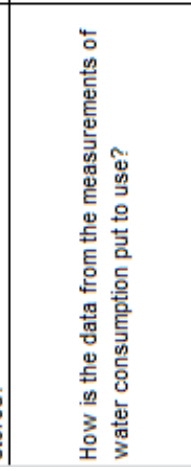 & 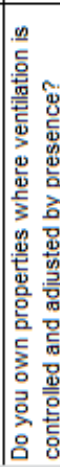 & 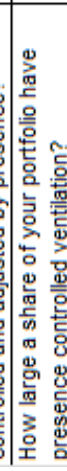 & 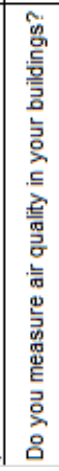 & 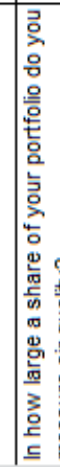 & 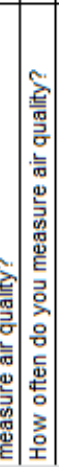 & 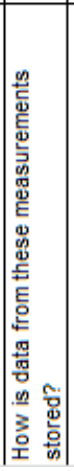 & 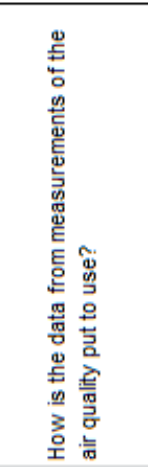 & 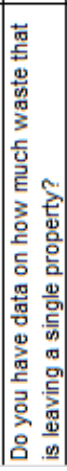 & 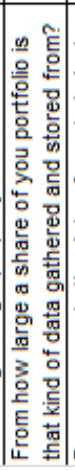 & 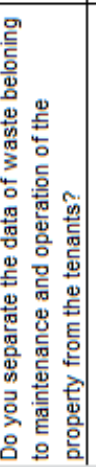 & 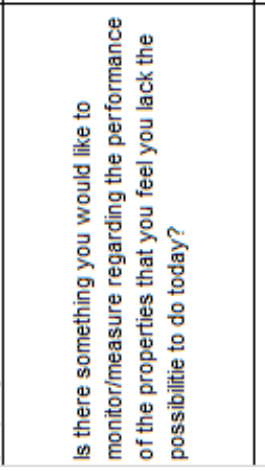 & 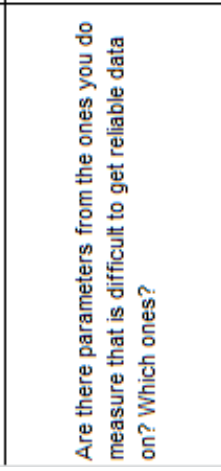 \\
\hline
\end{tabular}




\begin{tabular}{|c|c|c|c|c|c|c|c|c|c|c|c|c|c|c|c|}
\hline 9 & 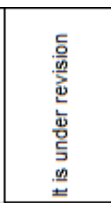 & 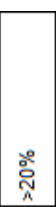 & $\stackrel{\mathscr{H}}{\zeta}$ & 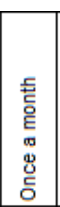 & 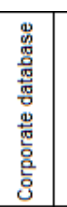 & 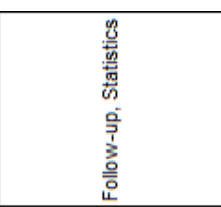 & 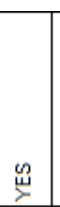 & 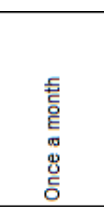 & 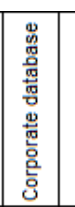 & 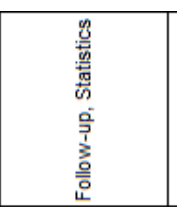 & $\stackrel{2}{2}$ & & & 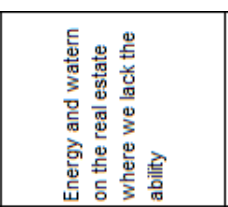 & \\
\hline$\approx$ & 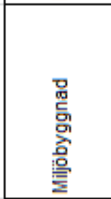 & : & $\stackrel{\mathscr{H}}{\nu}$ & 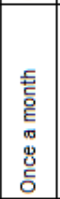 & 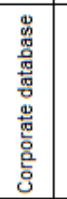 & 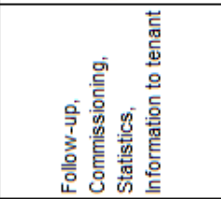 & 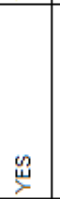 & 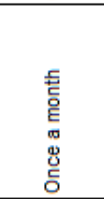 & 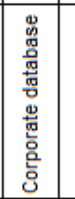 & & $\stackrel{\rho}{2}$ & & $\stackrel{\mathscr{\varkappa}}{\breve{\nu}}$ & & \\
\hline$=$ & 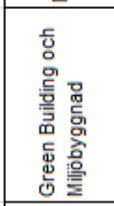 & 害 & $\stackrel{\mathscr{w}}{\rightleftharpoons}$ & 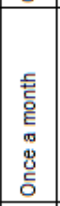 & 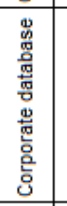 & 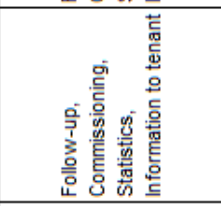 & $\stackrel{\mathscr{P}}{\forall}$ & 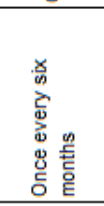 & 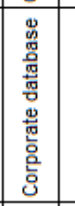 & 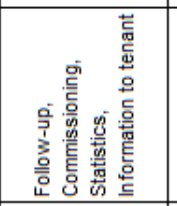 & $\stackrel{\mathscr{U}}{\dot{\psi}}$ & 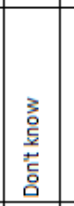 & $\stackrel{\mathscr{U}}{\nu}$ & 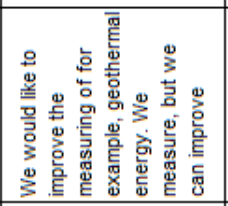 & 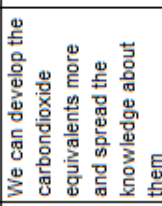 \\
\hline & 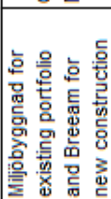 & ڤั่ & $\stackrel{\mathscr{H}}{\check{\gamma}}$ & 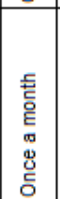 & 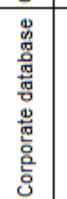 & 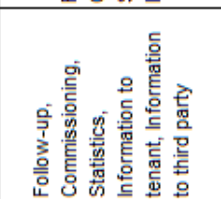 & ฉ & 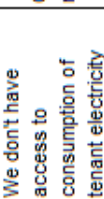 & 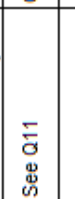 & 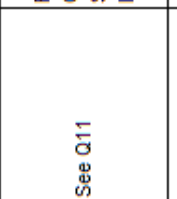 & $\stackrel{\text { o }}{z}$ & $\begin{array}{l}3 \\
\text { 产 } \\
\text { 童 } \\
\text { 空 }\end{array}$ & $\stackrel{\text { o }}{z}$ & 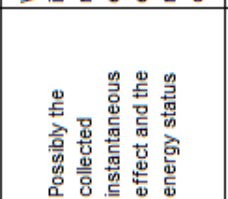 & \\
\hline & 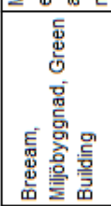 & 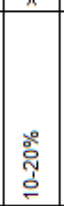 & $\stackrel{\mathscr{W}}{\breve{\nu}}$ & 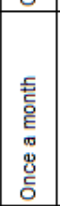 & 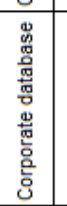 & 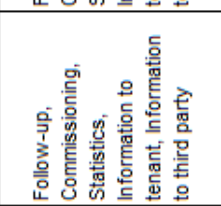 & $\stackrel{2}{2}$ & 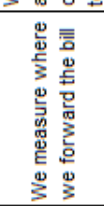 & 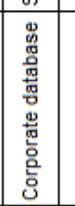 & 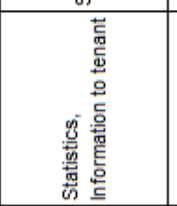 & 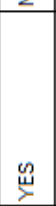 & $\frac{\circ}{\frac{0}{\lambda}}$ & $\stackrel{\mathscr{\nu}}{\breve{\nu}}$ & 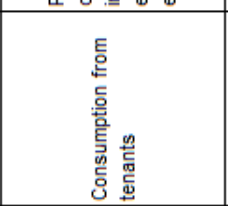 & 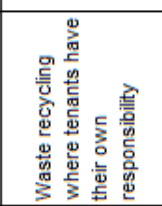 \\
\hline & 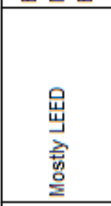 & : & $\stackrel{\mathscr{H}}{\vec{\nu}}$ & 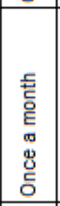 & 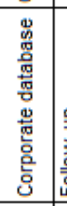 & 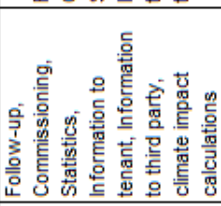 & $\stackrel{\mathscr{H}}{\rightleftharpoons}$ & 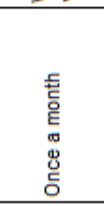 & 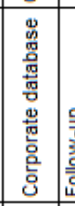 & 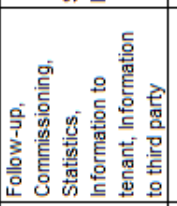 & 迳 & $\frac{\circ}{n}$ & 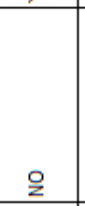 & 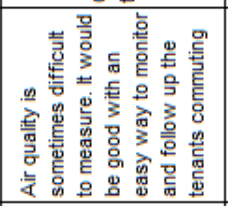 & 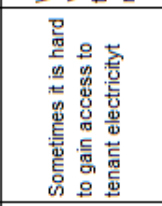 \\
\hline & $\bar{o}$ & g) & 8 & व & 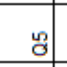 & 8 & $\tilde{\sigma}$ & $\stackrel{\circ}{\circ}$ & 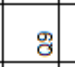 & $\begin{array}{r} \\
\end{array}$ & $\mathbb{z}$ & జ & ปี & \begin{tabular}{r|} 
gै \\
\end{tabular} & ฮั \\
\hline & 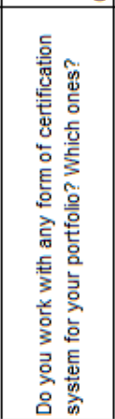 & 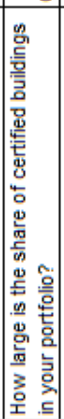 & 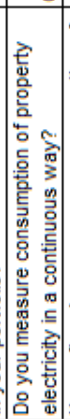 & & 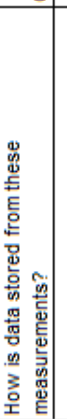 & 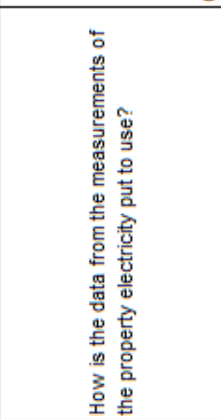 & 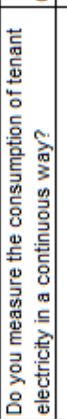 & 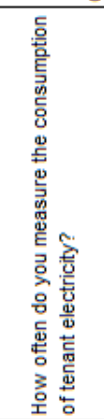 & 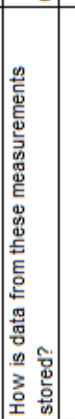 & 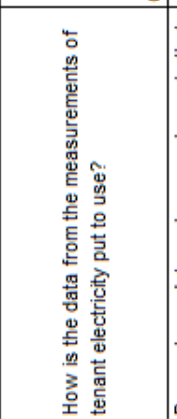 & 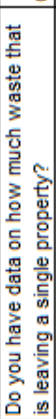 & 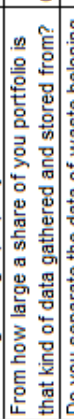 & 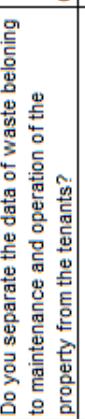 & 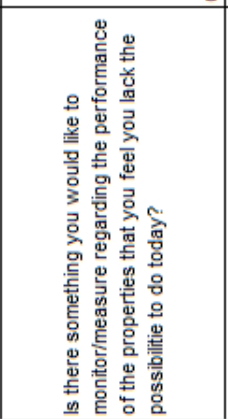 & 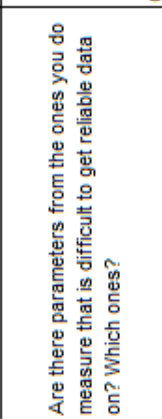 \\
\hline
\end{tabular}




\begin{tabular}{|c|c|c|c|c|c|c|c|c|c|c|c|c|c|c|c|}
\hline$\stackrel{\mathscr{P}}{\forall}$ & 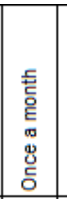 & 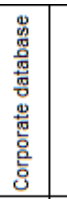 & 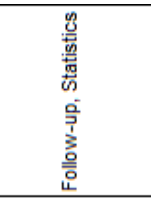 & $\frac{9}{2}$ & 器 & $\stackrel{\mathscr{ٌ}}{\breve{\nu}}$ & \%ั. & 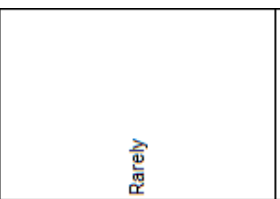 & & & $\stackrel{q}{z}$ & & & 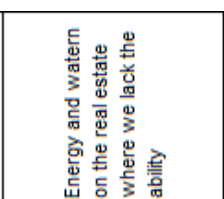 & \\
\hline$\stackrel{\mathscr{H}}{\succ}$ & 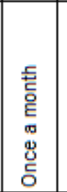 & 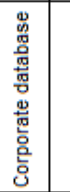 & 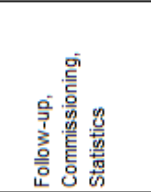 & $\stackrel{\infty}{\rightleftharpoons}$ & $\frac{\circ}{\frac{0}{2}}$ & $\stackrel{\circ}{2}$ & & & & & $\stackrel{\circ}{2}$ & & $\stackrel{\mathscr{\nu}}{\ddot{\nu}}$ & & \\
\hline$\stackrel{\mathscr{m}}{\forall}$ & 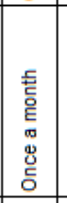 & 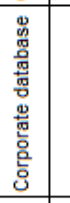 & 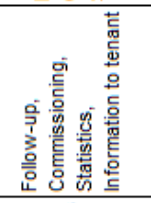 & $\stackrel{\mathscr{\nu}}{\stackrel{\nu}{~}}$ & $\frac{\circ}{\grave{n}}$ & 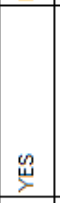 & $\frac{\circ}{\frac{0}{0}}$ & 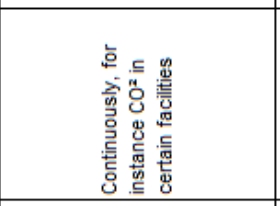 & 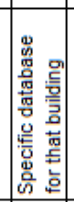 & 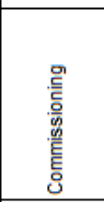 & $\stackrel{\mathscr{\infty}}{\breve{\nu}}$ & \begin{tabular}{|l|}
3 \\
co \\
童 \\
高 \\
\end{tabular} & $\stackrel{\mathscr{x}}{\dot{\psi}}$ & 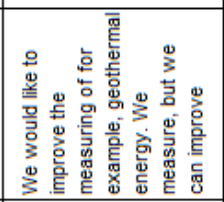 & 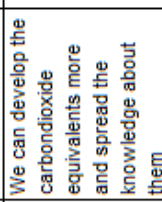 \\
\hline$\stackrel{\mathscr{S}}{\dot{\nu}}$ & 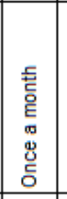 & 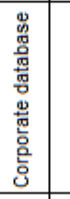 & 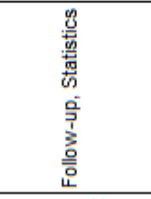 & $\stackrel{\mathscr{P}}{\sim}$ & 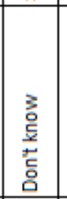 & 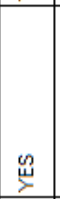 & 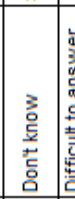 & 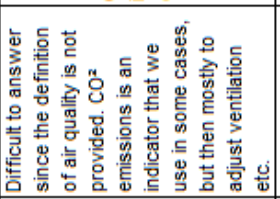 & & $\begin{array}{l}\mathbb{Z} \\
\mathbb{8} \\
\mathbb{8} \\
\end{array}$ & $\cong$ & 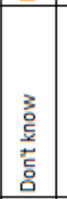 & $\stackrel{\circ}{z}$ & 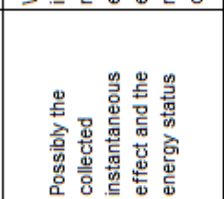 & \\
\hline$\stackrel{\mathscr{Z}}{\ddot{\nu}}$ & 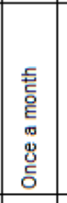 & 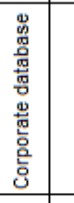 & 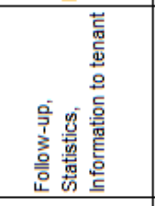 & $\stackrel{\mathscr{ٌ}}{\breve{\nu}}$ & 总 & $\stackrel{\mathscr{\varphi}}{\rightleftharpoons}$ & 总 & 產 & 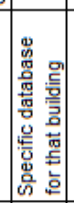 & 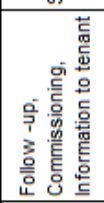 & $\stackrel{\mathscr{\psi}}{\forall}$ & $\frac{\circ}{2}$ & 这 & 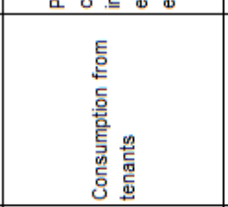 & 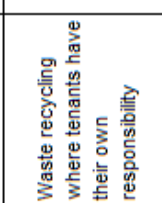 \\
\hline$\stackrel{\mathscr{P}}{\vec{\nu}}$ & 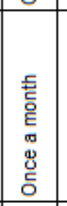 & 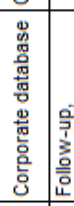 & 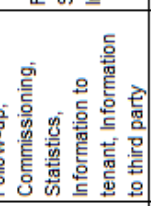 & \begin{tabular}{|l|}
$\stackrel{\leftrightarrow}{\nu}$ \\
\end{tabular} & \begin{tabular}{|l|} 
\\
产 \\
意 \\
总 \\
\end{tabular} & $\stackrel{\mathscr{\omega}}{\sqcup}$ & 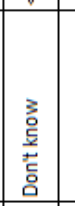 & 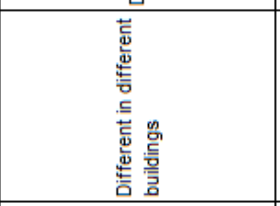 & 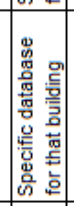 & 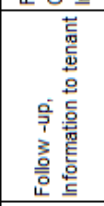 & \begin{tabular}{|c|c|}
$\stackrel{\leftrightarrow}{\nu}$ \\
\end{tabular} & $\frac{\circ}{\circ}$ & 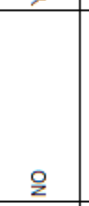 & 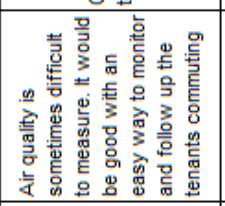 & 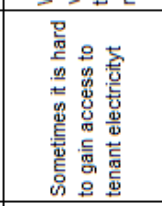 \\
\hline & $\frac{\pi}{0}$ & $\frac{0}{5}$ & $\frac{a}{0}$ & $\frac{5}{6}$ & $\frac{0}{0}$ & ธิธ & $\frac{\infty}{6}$ & $\frac{\circ}{0}$ & ธิธ & $\bar{\delta}$ & $\approx$ & ช్ & ปี่ & 敬 & है \\
\hline 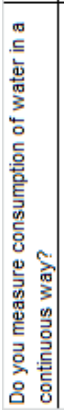 & 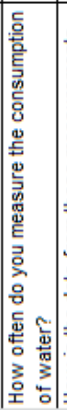 & 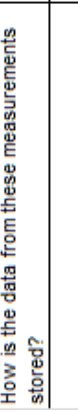 & 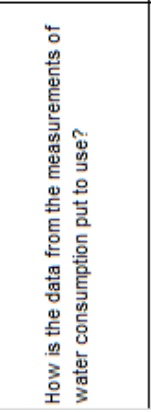 & 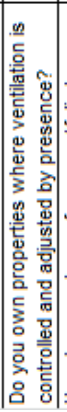 & 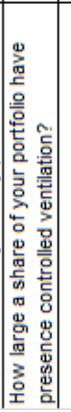 & 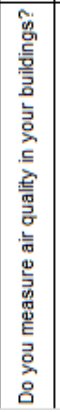 & 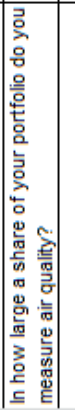 & 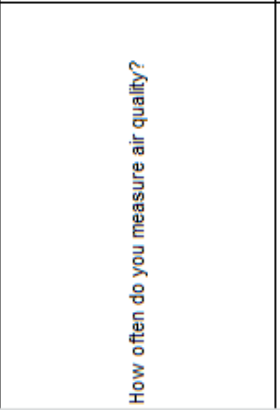 & 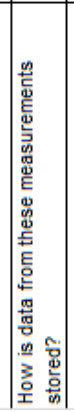 & 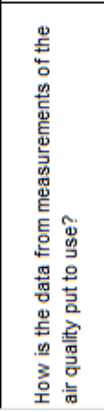 & 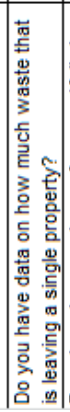 & 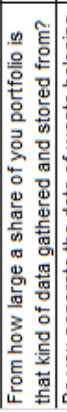 & 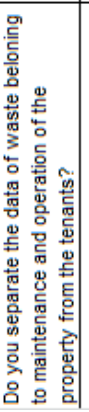 & 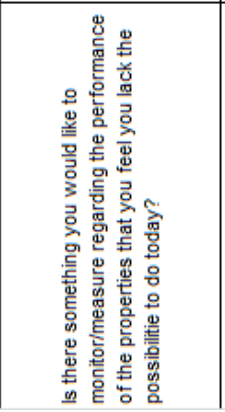 & 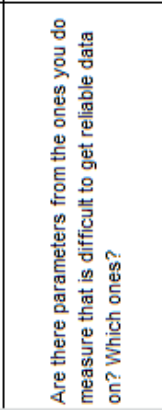 \\
\hline
\end{tabular}

